\title{
The Role of Vitamin D in Stunting Prevention: A Literature Review
}

\author{
Wiwi Mardiah $^{1,2 *} \mathbb{D}$, Budi Setiabudiawan $^{3} \mathbb{D}$, Henny Suzana Mediani ${ }^{1}(\mathbb{D}$ \\ ${ }^{1}$ Department of Pediatric Nursing, Faculty of Nursing, Universitas Padjadjaran, Bandung, Indonesia; ${ }^{2}$ Faculty of Medicine, \\ Universitas Padjadjaran, Bandung, Indonesia; ${ }^{3}$ Department of Child Health, Faculty of Medicine, Universitas Padjadjaran, \\ Bandung, Indonesia
}

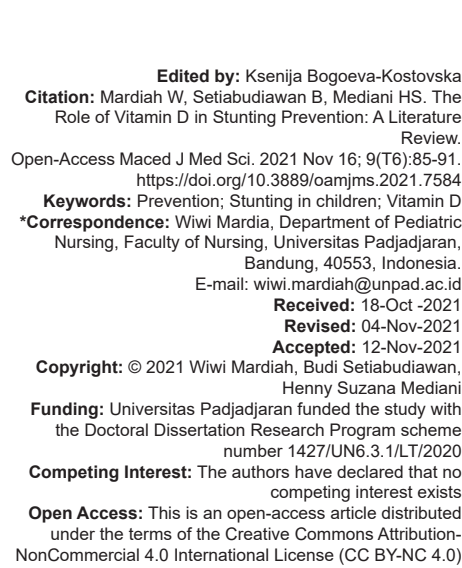

\section{Introduction}

Stunting is a chronic growth disorder in children due to a lack of nutrition for a long time. Stunting is one of the health problems experienced by toddlers in the world today, not least in Indonesia. In 2017, 22.2\%, which is around 150.8 million children under five in the world, experience stunting. Indonesia is included as it is the third country with the highest prevalence in the Southeast Asia Regional (SEAR). The average prevalence of stunting in toddlers in Indonesia in 2005 2017 was $36.4 \%$ [1]. Stunting is an issue in child nursing that must be prevented because of its very complex and detrimental impact on the various developmental sectors in Indonesia.

The first 1000 Days of Life (HPK) are an important period in stunting prevention, and this is followed by $270 \mathrm{HPK}$ during pregnancy, and $730 \mathrm{HPK}$ in children less than two years old. In the period of $1000 \mathrm{HPK}$, the need for vitamin $D$ is very necessary in connection to the process of metabolism for the purposes of bone growth and calcium balance. Vitamin D is a classic secosteroid. According to the Academy of Pediatrics (AAP), the need for vitamin $D$ in infants is as much as $400 \mathrm{IU} /$ day, both in infants who get exclusive breastfeeding and those who get complementary foods (PASI). This is because their vitamin $D$ needs are often not met only by exclusive breastfeeding or formula milk. According to the Center of Disease Control and Prevention (CDC) estimates, only $13-15 \%$ of infants who are breastfed and $20-37 \%$ of infants who receive formula milk are vitamin $D$ compliant according to the AAP recommendations.

Vitamin $D$ is processed automatically when the skin is exposed to ultraviolet light. When ultraviolet hits the skin, vitamin D3 (cholecalciferol) is a form of previtamin $D$ that is transferred to the blood and kidneys to be converted into the vitamin $D$ that the body needs. Ultraviolet A has a longer wavelength (320-400 nm) than Ultraviolet B (280-320 nm). The element Ultraviolet A is greater than Ultraviolet $\mathrm{B}$, and its rays are direct and uninterrupted from the sun. 
The vitamin $D$ levels in UVA have a longer wavelength (320-400 $\mathrm{nm}$ ) than UVB (280-320 nm). The term ultraviolet means "beyond purple", where the word "purple" is the color with the shortest wavelength in visible light. The UVA element is present directly and does not break from the sun. The serum is determined by two main factors, namely food intake and the vitamin D production in the skin when exposed to sunlight (ultraviolet B irradiation, UVB). Full-term babies are born with sufficient vitamin $D$ storage for the next few months, and the half-life of their vitamin $D$ serum is 12 - 20 days. Infant formula milk is often fortified with sufficient vitamin D (> 400 IU / L), whereas breast milk only contains $12-60$ IU / L vitamin D. This is far less than the maintenance amount needed (200 IU / day) as recommended by the National Academy of Science (NAS) [2].

Several factors can influence the process of vitamin D formation, namely skin color. People with a dark skin color must be longer exposed to UV light than people with a light skin color because dark skin contains more melanin. Melanin functions to protect the skin from damage due to excessive sun exposure. Melanin acts as a natural sunscreen to protect from the sun's UV rays in order to prevent skin cancer. The second factor is the duration of exposure to the UV rays. Some studies state that between 30 minutes and 12 seconds is ideal. There are also those that state that 15 minutes is enough, respective of other factors such as age. Being older decreases the ability of the body to produce vitamin $D$, alongside the thickness of clothing used and how many body parts are exposed to UV light. There are also the factors to do with the sun.

Other factors that influence the production of vitamin $D$ originating from the climate and the environment include cloudy weather meaning that the UV rays not being able to hit the skin, air pollution causing the UV rays to be reflected and the person's location as the sun's UV rays cannot penetrate walls. People who work indoors are still vulnerable to vitamin $\mathrm{D}$ deficiency.

Research related to vitamin D levels looks at the 1000 HPK obtained from several sources, namely Elsevier. In Tamblyn et al., (2015), research on the immunological role of vitamin $D$ in the maternal-fetal interface shows that the role of vitamin $D$ is very important in pregnancy [3]. Vitamin $D$ is key when it comes to regulating the immune function during pregnancy. The interface between the fetus and mother represents an important target. Among its non-classical actions are strong immunomodulatory effects, including the induction of an antibacterial response and the modulation of T-lymphocytes to suppress inflammation and increase tolerogenesis. Vitamin $D$ therefore plays an important role in the normal decidual immune function by promoting the innate response to infection while simultaneously preventing the excessive elaboration of immune inflammation. The research to date has focused on the potential role of vitamin $D$ in preventing infectious diseases such as tuberculosis, as well as possibly suppressing autoimmune diseases. However, vitamin $D$ can also affect aspects of the immune function that are not immediately related to the primary innate response. This review summarizes our current review of the decidual immune function with respect of vitamin $\mathrm{D}$ metabolism and signaling. This includes how this can be influenced by variations in maternal vitamin $D$ status. Recently, there has been a lot of interest in vitamin $D$ supplementation in pregnant women. Vitamin $D$ is known to be a classic secosteroid due to its key role in bone metabolism and calcium homoeostasis. Since the 1980s, there have been many additional 'non-classical' frameworks regarding the important functions of vitamin D including anti-proliferation, pro-differentiative, and powerful immunomodulatory actions. The purpose of this literature review was to analyze the role of vitamin $D$ in preventing stunting by identifying the role of vitamin $D$ and identifying the interventions used to promote vitamin D fulfillment as part of stunting prevention.

\section{Methods}

The articles were collected through the use of the Google Scholar, PubMed, Proquest, Ebsco databases using the keywords Vitamin D and Stunting, consisting of both quantitative and qualitative studies. The articles used were only the articles with a full text available that were written in English and Indonesian published from 2006 to 2019 . Fifteen articles were found that met the criteria. The quality of the methodology was assessed using the Critical Appraisal Skill Program guide and the PRISMA guide. Following this approach, only 5 articles met the criteria.

The PRISMAassessment diagram to determine the literature is as follows Figure 1:

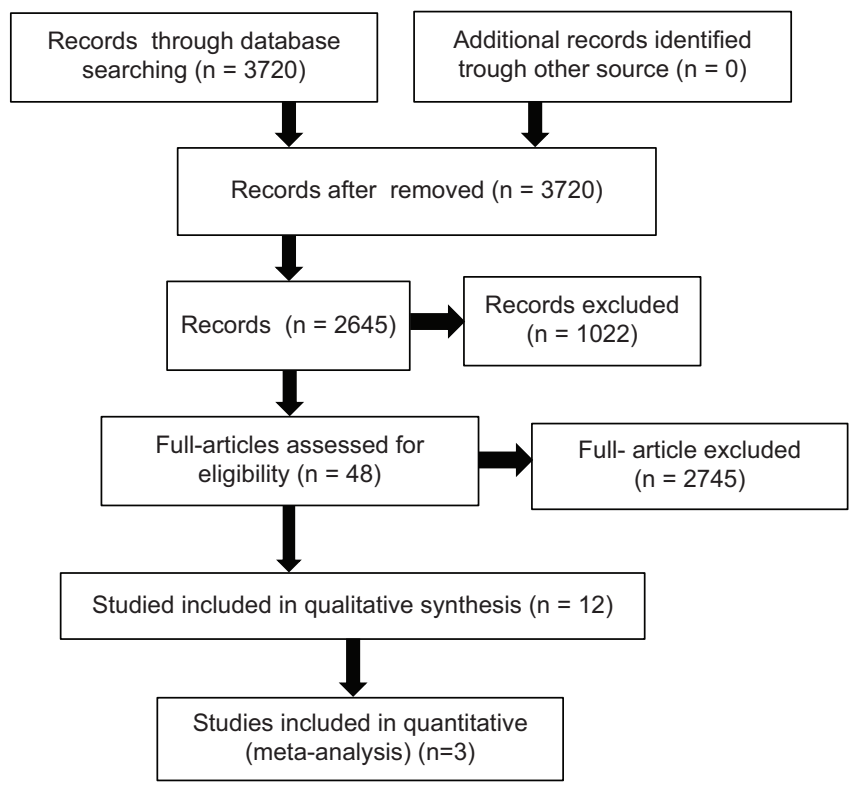

Figure 1: The PRISMA assessment diagram to determine the literature 


\section{Results}

The search results through the selected databases found 48 articles. Only 15 articles met the full criteria, specifically looking into the relationship between stress and the quality of life of mothers with thalassemic children. Chronic illnesses in children have a stunting effect besides the other psychological, social, spiritual, cultural, and economic impacts. Vitamin D has a very important role as it increases the mechanical defenses by increasing the level of immunity in children. The problem that is often faced today is that some people still do not take advantage of UVB sun exposure to fulfill their need for vitamin D. Some things that need to be considered in the process of vitamin $D$ formation have not been socialized such as skin color, UVB exposure being unable to penetrate the walls of most houses, and the time of exposure. All of these factors affect the metabolism of vitamin $D$ in the body.

The following is a table of characteristics of articles that meet the inclusion criteria:

Table 1: Characteristics of articles that meet the inclusion criteria

\begin{tabular}{llll} 
No. & Authors/years/place of study & Title & Patc \\
\hline 1 & Annie WC Kung, Ka Kui Lee, 2006, BMC & Knowledge of Vitamin D and \\
Public Health, http://wwwbiomedcentral. & $\begin{array}{l}\text { perceptions and attitudes toward } \\
\text { sunlight among Chinese middle age } \\
\text { com Hongkong, China [14]. }\end{array}$ & $\begin{array}{l}\text { and elderly women: A population } \\
\text { survey in Hongkong, }\end{array}$ \\
& & eld
\end{tabular}

2 Rana R Mokhtar, Michael F Holick1, Fernando Sempértegui, Jeffrey K Griffiths, Bertha Estrella, Lynn L Moore, Matthew P Fox and Davidson H Hamer (2017)

3 Dang Van Chuc, Nguyen Xuan Hung, Vuong Thi Trang, Dang Viet Linh, and Pham Minh Khue Tahun: 2019

4 Lan T. Ho-Pham, Mai T. T. Nguyen, (2012) Vietnam [13]

underweight and stunting in children months aged $6-36$ months residing in the Ecuadorian Andes
Nutritional Status of Children Aged 12-36 Months in a Rural District of Hungyen Province, Vietnam

Participant

elderly Chinese in Hongkong The survey results showed that $62.3 \%$ did not like going in the sun and $66.7 \%$ of respondents spent an average of $6-10$ $\mathrm{h}$ indoors, between $6.30 \mathrm{am}$ and $7.00 \mathrm{pm}$ during weekdays. However, $58 \%$ of people thought that they had enough exposure to sunlight

Cross-sectional analysis

Vitamin D status is associated with Children (n 516) aged 6-36

Nutritional status

Children aged 12-36 months

Anthropometric Measurement: Body weight, height/length, blood sample

Instrument: Anthropometric devices for weight and height measurements are calibrated annually for accuracy by the Ecuadorian National Standards Bureau. WAZ, Z height for age (HAZ) score and $Z$ weight for height (WHZ) score were calculated using WHO 2007 growth standards

The average serum concentration of $25(\mathrm{OH}) \mathrm{D}$ is 580

(SD 177) nmol/l. Sensitivity analysis revealed a cut-off of 25 $(\mathrm{OH}) \mathrm{D}$ specific malnutrition $<425 \mathrm{nmol} /$; $186 \%$ of children have serum $25(\mathrm{OH}) \mathrm{D}<425 \mathrm{nmol} / \mathrm{l}$. Children who are underweight are more likely to have serum $25(\mathrm{OH}) \mathrm{D}<42.5$ $\mathrm{nmol} / \mathrm{l}$ (adjusted OR $(\mathrm{aOR})=20 ; 95 \% \mathrm{Cl} 12,33)$. Children with low serum levels of $25(\mathrm{OH}) \mathrm{D}$ are more likely to be inhibited $(\mathrm{aOR}=28 ; 95 \% \mathrm{Cl} 16,47)$.

Conclusion: Low serum $\mathrm{D}(\mathrm{OH}) 25$ levels are more common in Ecuador children who are thin and stunted

$5 \quad$ Khem Pokhrel, Keiko Nanishi Krishna C. Undernutrition Among Infants Poudel Kalpana Gaulee Pokhrel Kalpana and Children in Nepal: Maternal Tiwari Masamine Jimba (2016) [17]
Health Services and Their Roles to Prevent it

Daniel E. Roth1, Alison D. Gernand Shaun K. Morris, Brendon Pezzack, M. Munirul Islam, Michelle C. Dimitris, Sha S. Shanta, Stanley H. Zlotkin, Andrew

R. Willan, Tahmeed Ahmed, Prakesh

S. Shah, Kellie E. Murphy, Rosanna

Weksberg, Sanaa Choufani, Rashed Shah and Abdullah Al Mahmud (2015) during pregnancy and lactation to promote infant growth in Dhaka, Bangladesh (MDIG trial): study trial
1160 children aged $12-36$ months in the commune to be reached. the final number is 327 children
Survey on knowledge and attitudes on Vitamin D and sunlight exposure in an urban population in Vietnam
Total Participants 1536 respondents with age between 18 and 85 years of age were surveyed
The multista sampling process is selected. Five communes (Ngocthanh, Vinhxa, Hungan, Hiepcuong, and Dongthinh) were randomly selected among 22 communes in the Kimdong district while the research subjects were selected by the sampling method. systematic sample

The prevalence of underweight, obstructed, wasted, and overweight/obese children was $7.6 \%, 23.5 \%, 6.7 \%$, and $1.2 \%$, respectively. The prevalence of anemia and Vitamin D deficiency was $33.3 \%$ and $47.7 \%$, respectively. Malnutrition, anemia, and Vitamin $\mathrm{D}$ deficiency are not statistically different by sex. Malnutrition and Vitamin $D$ deficiency do not differ statistically by age group, but anemia by age group there are significant differences

Knowledge, behavior, and attitudes of Vietnamese men and women toward Vitamin $D$ and sun exposure

A total of 1536 individuals aged $14-85$ years participated in this study. Fifty-three percent of the participants did not like being exposed to the sun. On average, most are reported to be around $14 \mathrm{~h} /$ week in the sun. The majority (81\%) reported that they had heard of Vitamin D from newspapers (32\%), friends $(20 \%)$ or radio and television (13\%). However, their knowledge of Vitamin D sources was inadequate: $37 \%$ thought that Vitamin D came from the sun, $28 \%$ came from food and sun, while $17 \%$ did not know the source of Vitamin D. Analysis of the determinants of Vitamin $D$ knowledge suggested that only the level of education is a significant predictor of Vitamin D knowledge

Cross-sectional study

Performed on a mother-child couple (ages 6 -23 months) in the Makawanpur district, Nepal. absence of PNC $(b=-1.01, p=0.011)$ were negatively related Nearly 400,000 people live in this to ICFI scores. In addition, the absence of ANC was positively district, including 18,000 children associated with underweight (AOR 3.37; 95\% Cl 1.42-9.92 aged $0-23$ months for children)

Selected 400 mother-child pairs in rural Nepal

Maternal Vitamin D supplementation A total of 1300 pregnant women Randomized control trial protocol for a randomized controlled will be randomized, with the The role of Vitamin $D$ in the health of mothers and infants is each group insights about the impact of increasing maternal-infant Vitamin D status in low-income environments where inhibited and detrimental perinatal outcomes represent a significant public health burden. 
$7 \quad$ Mie Shiraisihi, Megumi Haruna, Massayo Matsuzaki, Ryoto Murayama, Sachiko Kitanaka, 2015, Maternal and Child Nutrition [18]

8 Mi-Jung Kim, MD Departemen Pediatri, Rumah Sakit Universitas Nasiona Chungbuk, 410 Sungbong-ro, Heungduk-gu, Cheongju 361-711, Korea.

9 Nidya Ikha Putri, Nur Indrawaty Lipoeto, Rauza Sukma Rita, Arif Sabta Aj e-mail: nidyaikhap@gmail.com [20]
Validity of self- administered diet history questionnaire for estimating Vitamin D intake of Javanese Pregnant women

Vitamin D Nutritional Status and Effects of Vitamin D Supplementation on Breastfeeding Infants in Korea

74 newborns and their mothers 245 healthy pregnant women in second trimester

(10

\section{serur} dministered diet history questionnaire (DHQ) and Using serum marker

To assess the test-retest reliability of the DHQ, 58 pregnant women completed it twice within a 4-5 week interval. Significant positive correlation between intake and serum concentration of Vitamin D

Serum samples were stored at $-20^{\circ} \mathrm{C}$ in a light-resistant bottle before biochemical testing at Green-Cross Laboratory, Seoul, Korea. Serum concentration of 25 OHD 3 was measured by radioimmunoassay $(25 \mathrm{OH}-\mathrm{VIT}$.D3-RIA-CA kit, BioSource, Europe; coefficient of intra-assay and interassay variation, 4.7 and 5.3 , respectively and PTH (iPTH) intact by electrochemiluminescence intact (reference: $15-65 \mathrm{pg} / \mathrm{dL}$ )

Relationship of Vitamin D Levels in Pregnant women who met the

conducted in Tanah Datar District

Taking blood from the mother using disposable syringes through the vein mediana cubiti. Before the examination Pregnant Women with Birth Weight inclusion and exclusion c of Babiesi Solok of Distric

with a total of 60 respondents. Inclusion criteria include, pregnant women with gestational is age $\geq 28$ weeks, pregnant women aged 20 years to reach 35 years, pregnancy spacing $>2$ years, and are willing to become respondents

Dietary Vitamin $D$ dose-response in Participants aged $2-8$ years healthy children $2-8$ years of age: a $\quad(n=77$; Montreal, Canada $)$ 12-week randomized controlled tria using fortified foods) is done, the blood that has been taken is inserted into a centrifuge tube with a speed of $3000 \mathrm{rpm}$ and allowed to stand for 15 min until it freezes. The blood sample is coded, then sent to the Biomedical laboratory for examination of levels of $25(\mathrm{OH})$ D using a Human $25(\mathrm{OH}) \mathrm{D}$ ELISA KIT Distribution of respondents based on maternal age, weight of pregnant women, height of pregnant women, Vitamin D Status of Pregnant Women Trimester III, Average Vitamin D Levels in Trimester III Pregnant Women and Average Vitamin D Levels in newborns.

The average value of Vitamin D levels in pregnant women is $25.44 \mathrm{ng} / \mathrm{ml}$ with a standard deviation of $10.49 \mathrm{ng}$, and the average value of Vitamin $D$ levels in newborns is $3066.67 \pm 328.15$ randomly assigned to 1 of 3 dietary Vitamin $D$ targets (control; EAR: $400 \mathrm{IU} / \mathrm{d}$; or RDA: $600 \mathrm{IU} / \mathrm{d}$ ) for 12 week (January to April 2014). Anthropometric measurements, demographic characteristics, dietary intakes, fasting serum parathyroid hormone, 25-hydroxyvitamin $\mathrm{D}[25(\mathrm{OH}) \mathrm{D}]$, and ionized calcium were compared using mixed model ANOVA

Participants' mean 6 SD age was $5.1,61.9$ years; $54.5 \%$ were boys with body mass index $z$ scores of 0.5060 .85 . Compliance was $85 \%$ overall. No differences were observed in baseline dietary Vitamin D intakes or serum $25(\mathrm{OH}) \mathrm{D}$. At 12 weeks, the EAR and RDA groups had significantly higher Vitamin D intakes (median [IQR]: control, 227 [184-305] IU/d; EAR, 410 [363-516] IU/d; and RDA, 554 [493-653] IU/d; p, 0.05 ) and serum $25(\mathrm{OH}) \mathrm{D}$ concentrations (control: 55.86 $12.3 \mathrm{nmol} / \mathrm{L}$; EAR: $64.1610 .0 \mathrm{nmol} / \mathrm{L}$; and RDA: 63.7612 .4 $\mathrm{nmol} / \mathrm{L} ; \mathrm{p}, 0.05$ ) than the control group. Ninety-six percent of children in the EAR and RDA groups and $67 \%$ of the control group had $25(\mathrm{OH}) \mathrm{D}$ concentrations at $\$ 50 \mathrm{nmol} / \mathrm{L}$.

Conclusion: Increasing the Vitamin $D$ intakes of young children through fortification of alternative dairy products results in significantly higher serum concentrations of $25(\mathrm{OH}) \mathrm{D}$ and a significantly greater proportion of children with serum $25(\mathrm{OH})$ D $\$ 50 \mathrm{nmol} / \mathrm{L}$ during periods of minimal ultraviolet $B$ radiation exposure. This trial was registered at clinicaltrials.gov as NCT02097160 and had Health Canada Temporary Marketing Authorization Letters for both products (TM-13-0432 and TM-13-0433).

Results: The overall prevalence of stunting was $36.9 \%$ (Cl 29.2, 44.6) and increased with age, being $49 \%$ in the 4-5-year-old age category. Birth weight correlated significantly with height-for-age $z$ scores (HAZ; $r 1 / 40.250, p^{1 / 4} 40.003$ ), and was lower in children whose mothers smoked and used alcoho during pregnancy than in children whose mothers abstained $(p<0.0001)$. Median intake of energy, carbohydrate and protein was adequate. Median intake for all micronutrients was at least $90 \%$ of the estimated average requirement, except for calcium, Vitamin D and Vitamin E, which was $21 \%, 15 \%$, and $32 \%$, respectively. Intake of fat, calcium, phosphorous, Vitamin D, riboflavin, and Vitamin B12 (nutrients that typically occur in milk) was significantly lower in stunted than in nonstunted children $(p<0.05)$. When excluding children with low birth weight, intake of calcium, Vitamin $D$, and riboflavin were still significantly lower $(p<0.05)$. HAZ was higher in children who habitually drank milk compared to those who did not $(p=0.003)$ May 2010 and August 2011

The research was observational with cross-sectional design. This research showed that $35.85 \%$ sample underweight, $60.38 \%$ well-nourished, and $3.77 \%$ overweight. The data after height/ age measurement has shown that $9.43 \%$ sample were short $73.58 \%$ normal and $16.98 \%$ tall 


\begin{tabular}{|c|c|c|c|c|}
\hline 13 & $\begin{array}{l}\text { Helve, Viljakainen Holmlund-Suila, } \\
\text { Rosendahl, Hauta-Alus, Enlund-Cerullo, } \\
\text { Valkama, Heinonen, Räikkönen, } \\
\text { Hytinantti, Mäkitie, Andersson. (2017) } \\
\text { [21] }\end{array}$ & $\begin{array}{l}\text { Toward evidence-based Vitamin D } \\
\text { supplementation in infants: Vitamin D } \\
\text { intervention in infants (VIDI) }\end{array}$ & & $\begin{array}{l}\text { Study design and methods of a randomized controlled double- } \\
\text { blinded intervention study) } \\
\text { Double-blind randomized testing was performed on infants } \\
\text { ranging from } 2 \text { weeks to } 24 \text { months. Participants recruited } \\
\text { randomly received daily } 10 \mathrm{mg} \text { ( } 400 \mathrm{IU}) \text { or } 30 \mathrm{mg} \text { ( } 1200 \mathrm{IU} \text { ) of } \\
\text { Vitamin D supplementation. Both groups were assessed at age } \\
6 \text { months for calcium homeostasis and } 12 \text { months were related } \\
\text { to bone strength, growth, development, atopic disease, genetic } \\
\text { Epidemiological studies and randomized trials show conflicting } \\
\text { results. For example there are quite a lot of effects of Vitamin } \\
\text { D supplements on children's infections and neurocognitive } \\
\text { function. The results of this study are likely to produce new } \\
\text { evidence-based information to improve Vitamin D status in } \\
\text { children. }\end{array}$ \\
\hline 14 & $\begin{array}{l}\text { Nandita Perumal, Abdullah Al Mahmud, } \\
\text { Abdullah H Baqui, Daniel E Roth (2015) }\end{array}$ & $\begin{array}{l}\text { Prenatal Vitamin D supplementation } \\
\text { and infant Vitamin D status in } \\
\text { Bangladesh) }\end{array}$ & $\begin{array}{l}\text { Infants born to pregnant women } \\
\text { (n 160) }\end{array}$ & $\begin{array}{l}\text { Prenatal Vitamin D supplementation and infant Vitamin } D \\
\text { status in Bangladesh. } \\
\text { The findings in this study indicate that in considering the } \\
\text { potential for Vitamin } D \text { in postnatal babies as regulated in } \\
\text { Bangladesh, an increase of } 25(\mathrm{OH}) \mathrm{D} \text { in the absence of } \\
\text { Vitamin } D \text { supplementation must be recognized. Future } \\
\text { research should aim to address the effects of Vitamin } D \\
\text { supplementation on pregnant women for infant health }\end{array}$ \\
\hline 15 & $\begin{array}{l}\text { Gallo T. HazellC. A. VanstoneS. Agellon } \\
\text { G. JonesM. L'AbbéC. RoddH. A. } \\
\text { WeilerEmail (2016) [22] }\end{array}$ & $\begin{array}{l}\text { Vitamin D supplementation in } \\
\text { breastfed infants from Montréal, } \\
\text { Canada: } 25 \text {-hydroxyvitamin } D \text { and } \\
\text { bone health effects from a follow-up } \\
\text { study at } 3 \text { years of age) }\end{array}$ & 132 respondents & $\begin{array}{l}\text { METHOD: Double-blind randomized trial of } 132 \text { respondents. } \\
\text { At the age of } 1 \text { month respondents were randomly assigned to } \\
\text { receive oral Vitamin D3 support for up to } 12 \text { months. } 87 \text { babies } \\
\text { were returned for follow-up at the age of } 3 \text { years. } \\
\text { At the age of } 1 \text { month, participants randomly received oral } \\
\text { cholecalciferol (Vitamin D3) supplements } 400,800,1200 \text {, or } \\
1600 \text { IU/day until } 12 \text { months of age. Spinal lumbar } 1-4 \text { (LS) } \\
\text { bone mineral density (BMD), LS and all bone mineral content } \\
\text { (BMC), and mineral accretion are measured by double-energy } \\
\text { X-ray absorptiometry at } 3 \text { years } \\
\text { Instrument: Stadiometer (Secca } 213 \text {, Secca Medical Scale, } \\
\text { and Measuring System). Calibrate scale (Detecto). } \\
\text { Results: There were no significant differences at } 25 \text { (OH) } \\
\text { D concentrations. No differences between the Vitamin D } \\
\text { treatment groups were recorded for BMC, BMD, or BMD Z } \\
\text { scores. There was no effect of Vitamin D status on } 3 \text { years of } \\
\text { bone related biomarkers including ionized calcium. } \\
\text { At follow-up, the treatment group was similar in terms of diet, } \\
\text { sun exposure, and demographics. There were no significant } \\
\text { differences between groups in LS or whole body BMC, BMD, } \\
\text { or accretion. Although, } 25 \text { (OH) D concentrations did not } \\
\text { differ between groups, higher doses ( } 1200 \text { and } 1600 \text { IU/day) } \\
\text { reached a higher D (OH) D area under the curve from } 1 \text { to } 36 \\
\text { months versus } 400 \text { IU/day } \\
\text { This is the first longitudinal follow-up of an infant Vitamin D } \\
\text { dose-response study which examines bone mineralization at } 3 \\
\text { years of age. Dosages higher than } 400 \text { IU/day do not appear } \\
\text { to provide additional benefits to the bone at follow-up. Larger } \\
\text { studies with more ethnically diverse groups are needed to } \\
\text { confirm these results }\end{array}$ \\
\hline
\end{tabular}

\section{Discussion}

Based on the results of the literature review, the articles contain several concepts focused on UVB exposure and Vitamin D.

\section{The role of Vitamin D}

Vitamin $D$ is a fundamental nutrient in the building of bone mineral. This study has enabled the evaluation of the short- and long-term effects of supplemental vitamin D on growth, immune functions, and the skeletal and developmental parameters in infants. This is as well as the effects of the genetic factors involved. The results enable the drawing up of evidence-based guidelines for vitamin $D$ supplementation in infancy.

According to Otto Helve, Heli Viljakainen, Elisa Holmlund-Suila et al., biologically inactive vitamin D3 (cholecalciferol) is produced in the skin after solar UVB exposure. It is bound to the vitamin $D$ binding protein
(DBP) and transported to the liver for conversion into 25-hydroxy-vitamin D (25-OHD). This is the most abundant circulating metabolite of vitamin $\mathrm{D}$. In the kidneys, 25-OHD is further hydroxylated into the active form of calcitriol, 1,25-OH2D. This contributes to the metabolism of calcium.

\section{UVB exposure and Vitamin D}

Because the exposure of the skin to solar UVB radiation and therefore skin-based vitamin $D$ production are the main sources of vitamin D for most people, areas with a low latitude should theoretically have a low prevalence of vitamin $\mathrm{D}$. Vitamin $\mathrm{D}$ deficiency is of particular concern in growing children. Limited data is available on the relationship between vitamin $D$ and nutritional status. One study found that children who are underweight (defined by their BMI Z-score) have a higher risk of vitamin D deficiency. This is supported by the research conducted by Mokhtar, et al, (2017). Based on their quantitative research, it was identified that it is possible to measure the prevalence of vitamin $\mathrm{D}$ deficiency against the socio-economic status (SES) 
of a child's body weight [4]. The children were aged 6-36 months living in the Andes of Ecuador. Their vitamin $D$ status was assessed differently depending on whether they were underweight or of a normal weight. It was determined that there were lower vitamin $D$ levels among the children who were more likely to be stunted.

The same can be seen in the research of Chuc, et al., (2019) [11] on the nutritional status of children aged 12 to 36 months in a rural district of Hungyen Province, Vietnam. It is said that malnutrition can influence their physio-psychological development which leads to a lower level of performance and productivity as the children grow [5]. The most common form of malnutrition is stunting. This affects 156 million children on a worldwide scale today.

Maternal vitamin D supplementation during pregnancy and lactation to promote infant growth in Dhaka, Bangladesh (MDIG trial), used a protocol as part of a randomized controlled trial [6]. They determined that vitamin $D$ regulates bone mineral metabolism and bone development. Prenatal vitamin D deficiency increases the risk of adverse pregnancy and / or adverse birth outcomes. Little is known about the effect of maternal vitamin D status on the infant's linear growth in communities in South Asia where stunting is very prevalent and where the maternal-infant vitamin $D$ status is generally suboptimal [12].

\section{Stunting and Vitamin D}

The children's height is one indicator of stunting alongside the chronic diseases that accompany it. Height in children can indicate the stunted growth of their bones. One important element in bone growth is vitamin D. Levels of 25-hydroxyvitamin are a benchmark of a person with vitamin $D$ deficiency. Deficiency is determined if the serum 25-hydroxyvitamin $D$ level is less than $20 \mathrm{ng}$ per $\mathrm{mL}(50 \mathrm{nmol}$ per $\mathrm{L})$.

In addition to vitamin $\mathrm{D}$, bone growth is focused through the use of calcium and phosphorus. Vitamin $D$ is an essential vitamin. It is a class of fat-soluble secosteroids and it is incorporated as a modulator that is needed in the process of growth and calcium balance. The American Academy of Pediatrics determined that infants and children should receive more than $400 \mathrm{IU}$ per day from their diet and supplements. Evidence shows that vitamin D supplementation of at least 700 to $800 \mathrm{IU}$ per day reduces the risk of fracture at a decreased rate in adults. In people with vitamin D deficiency, treatment may include oral ergocalciferol (vitamin D2) at 50,000 IU per week for weeks. After their vitamin $D$ levels become normal, experts increase the maintenance dose of cholecalciferol (vitamin D3) from 800 to 1,000 IU per day from both their food sources and additives. [15]

Several studies have shown that the vitamin D levels are low in children who are not adolescents, as well as pregnant women and infants under five years old (toddlers). According to Judistiani RDT et al, 2018 in the research on the association of colecalciferol, ferritin, and anemia among pregnant women, the results from their cohort study on Vitamin D status and its effects during pregnancy and childhood in Indonesia showed that 203 women were recruited. Out of this total, 195 $(96,06) \%)$ suffered from hypovitaminosis D, 52 (75\%) had vitamin $D$ levels that were deficient, and 43 women $(21 \%)$ had an inadequate intake of vitamin D.

Vitamin D is found in fish and some vegetables, as well as select meat, poultry, and dairy products (without fortification). Apart from food sources, vitamin $\mathrm{D}$ can also be obtained by basking in the sun during the day between 11:00am to 13:00pm for 37 minutes and 12 seconds minimum. Daytime sunlight contains ultraviolet B (UVB) that penetrates the epidermis and changes the provitamin D3 (cholecalciferol) response into previtamin D3. This binds to the vitamin $D$ binding proteins that are to be transported through the blood circulation or stored in fat and used to help the liver [8].

\section{Conclusion}

The analysis of the fifteen articles that have been reviewed concludes that the findings of all studies show that stunting has a significant impact on children under five. The impact that appears in this literature is caused by several factors. The factors cause stress to the parent / mother, meaning that the quality of life of the mother becomes no better during the process of caring for their child with thalassemia due to the pressure experienced. This research might be useful in terms of increasing the available information about thalassemia and raising the awareness of nurses and other healthcare individuals.

\section{References}

1. Ministry of Health Republic of Indonesia, Situasi Balita Pendek d Indonesia; 2018. Available from: https://www.pusdatin.kemkes. go.id/folder/view/01/structure-publikasi-pusdatin-buletin.html [Last accessed on $2021 \mathrm{Jul} 23$ ].

2. Nutritional status of Vitamin $D$ and the effect of Vitamin D supplementation in Korean breast-fed infants. J Korean Med Sci. 2010;25(1):83-9. https://doi.org/10.3346/jkms.2010.25.1.83 PMid:20052352

3. Tamblyn JA, Hewison M, Wagner CL, Bulmer JN, Kilby MD. Immunological role of Vitamin $\mathrm{D}$ at the maternal-fetal interface. J Endocrinol. 2015;224(3):R107-21. https://doi.org/10.1530/ JOE-14-0642

PMid:25663707

4. Mokhtar RR, Holick MF, Sempértegui F, Griffiths JK, Estrella B, Moore LL, et al. Vitamin D status is associated with underweight 
and stunting in children aged 6-36 months residing in the Ecuadorian Andes. Public Health Nutr. 2018;21(11):1974-85. https://doi.org/10.1017/S1368980017002816

PMid:29162164

5. Chuc DV, Hung NX, Trang VT, Linh DV, Khue PM. Nutritional status of children aged 12 to 36 months in a rural district of hungyen province, Vietnam. Biomed Res Int. 2019;2019:6293184. https://doi.org/10.1155/2019/6293184 PMid:31111061

6. Roth DE, Gernand AD, Morris SK, Pezzack B, Islam MM, Dimitris MC, et al. Maternal Vitamin D supplementation during pregnancy and lactation to promote infant growth in Dhaka, Bangladesh (MDIG trial): Study protocol for a randomized controlled trial. Trials. 2015;16:300. https://doi.org/10.1186/ s13063-015-0825-8

PMid:26169781

7. Bordelon P, Ghetu MV, Langan RC. Recognition and management of Vitamin $D$ deficiency. Am Fam Physician. 2009;80(8):841-6.

PMid: 19835345

8. Mulligan ML, Felton SK, RiekAE, Bernal-Mizrachi C. Implications of Vitamin $D$ deficiency in pregnancy and lactation. Am J Obstet Gynecol. 2010;202(5):429.e1-9. https://doi.org/10.1016/j. ajog.2009.09.002

PMid: 19846050

9. Ariati NN, Fetria A, Purnamawati AA, Suarni NN, Padmiari IA Sugiani PP. Description of nutritional status and the incidence of stunting children in early childhood education programs in Bali-Indonesia. Bali Med J. 2018;7(3):723-26. https://doi. org/10.15562/bmj.v7i3.1219

10. Perumal N, Al Mahmud A, Baqui AH, Roth DE. Prenatal Vitamin D supplementation and infant Vitamin $D$ status in Bangladesh. Public Health Nutr. 2017;20(10):1865-73. https:// doi.org/10.1017/S1368980015003092 PMid:26541060

11. Yunitasari E, Pradanie $R$, Arifin $H$, Fajrianti D, Lee $B O$. Determinants of stunting prevention among mothers with children aged 6-24 Months. Open Access Maced J Med Sci. 2021;9(B):378-84.

12. Shin JS, Choi MY, Longtine MS, Nelson DM. Vitamin D effects on pregnancy and the placenta. Placenta. 2010;31(12):1027-34. https://doi.org/10.1016/j.placenta.2010.08.015 PMid:20863562

13. Ho-Pham L, Nguyen M. Survey on knowledge and attitudes on Vitamin $D$ and sunlight exposure in an urban population in Vietnam. J ASEAN Fed Endocr Soc. 2012;27(2):191-5.

14. Kung AW, Lee KK. Knowledge of vitamin $D$ and perceptions and attitudes toward sunlight among Chinese middle-aged and elderly women: A population survey in Hong Kong. BMC Public Health. 2006;6:226. https://doi.org/10.1186/1471-2458-6-226 PMid: 16956420

15. Wagner CL, Hollis BW. The implications of Vitamin D status during pregnancy on mother and her developing child. Front Endocrinol (Lausanne). 2018;9:500. https://doi.org/10.3389/ fendo.2018.00500

PMid:30233496

16. Brett NR, Lavery P, Agellon S, Vanstone CA, Maguire JL, Rauch $\mathrm{F}$, et al. Dietary Vitamin $\mathrm{D}$ dose-response in healthy children 2 to 8 y of age: A 12-wk randomized controlled trial using fortified foods. Am J Clin Nutr. 2016;103(1):144-52. https://doi.org/10.3945/ajcn.115.115956 PMid:26675772

17. Pokhrel K, Nanishi K, Poudel KC, Pokhrel KG, Tiwari K, Jimba M. Undernutrition among infants and children in Nepal: Maternal health services and their roles to prevent it. Matern Child Health J. 2016;20(10):2037-49. https://doi.org/10.1007/ s10995-016-2023-z PMid:27236701

18. Shiraishi M, Haruna M, Matsuzaki M, Murayama R, Kitanaka S, Sasaki S. Validity of a self-administered diet history questionnaire for estimating Vitamin D intakes of Japanese pregnant women. Matern Child Nutr. 2015;11(4):525-36. https://doi.org/10.1111/mcn.12063 PMid:24118748

19. van Stuijvenberg ME, Nel J, Schoeman SE, Lombard CJ, du Plessis LM, Dhansay MA. Low intake of calcium and Vitamin D, but not zinc, iron or Vitamin $A$, is associated with stunting in 2-to 5-year-old children. Nutrition. 2015;31(6):841-6. https://doi. org/10.1016/j.nut.2014.12.011 PMid:25933491

20. Putri NI, Lipoeto NI, Rita RS, Aji AS. The relationship between vitamin D levels in pregnant women and birth weight in Tanah Datar and Solok districts. J IIm Univ Batanghari Jambi. 2019;19(1):61.

21. Helve $O$, Viljakainen $H$, Holmlund-Suila $E$, Rosendahl $J$, Hauta-Alus $\mathrm{H}$, Enlund-Cerullo $\mathrm{M}$, et al. Toward evidence-based vitamin $D$ supplementation in infants: Vitamin $D$ intervention in infants (VIDI)-study design and methods of a randomised controlled double-blinded intervention study. BMC Pediatr. 2017;17(1):91. https://doi.org/10.1186/s12887-017-0845-5 PMid:28356142

22. Gallo S, Hazell T, Vanstone CA, Agellon S, Jones G, L'Abbé $M$, et al. Vitamin $D$ supplementation in breastfed infants from Montréal, Canada: 25-hydroxyvitamin D and bone health effects from a follow-up study at 3 years of age. Osteoporos Int. 2016;27(8):2459-66. https://doi.org/10.1007/ s00198-016-3549-z PMid:26968165

Author Queries???

AQ5: Kindly cite references 10 in the text part and citation are not in chronological order please check and provide 